\title{
Family Ownership, Independent Oversight, and Financial Information Transparency: Evidence From Asia
}

\author{
SITI NUKE NURFATIMAH \\ Universitas Kuningan \\ ZUNI BAROKAH* \\ Universitas Gadjah Mada
}

\begin{abstract}
This study examines the association between family ownership and financial information transparency of large corporations in the Asian region and whether independent oversight (i.e., independent directors and external auditors) influences such relationship. The transparency of financial information is measured using earnings' opacity which includes three dimensions, i.e., profit aggressiveness, loss avoidance, and income smoothing. The findings show a positive association between family ownership and financial information transparency. Further, we find that both independent director and external auditors negatively influence the relationship between family ownership and financial information transparency. Firms with a higher percentage of family ownership tend to have a weaker role of board independence, which leads to less transparent financial information. Lastly, external auditors also seem to have limited power in reducing earnings opacity in family firms.
\end{abstract}

Keywords: financial information transparency, earnings' opacity, family ownership, board independence, external auditors

Intisari: Studi ini meneliti hubungan antara kepemilikan keluarga dan transparansi informasi keuangan perusahaan besar di kawasan Asia dan apakah pengawasan independen (yaitu, direktur independen dan auditor eksternal) memengaruhi hubungan semacam itu. Transparansi informasi keuangan diukur menggunakan opacity laba yang mencakup tiga dimensi, yaitu, agresivitas laba, penghindaran kerugian, dan perataan laba. Temuan menunjukkan hubungan positif antara kepemilikan keluarga dan transparansi informasi keuangan. Lebih lanjut, kami menemukan bahwa direktur independen dan auditor eksternal berpengaruh negatif terhadap hubungan antara kepemilikan keluarga dan transparansi informasi keuangan. Perusahaan dengan persentase kepemilikan keluarga yang lebih tinggi cenderung memiliki peran independensi dewan yang lebih lemah, yang mengarah pada informasi keuangan yang kurang transparan. Terakhir, auditor eksternal juga tampaknya memiliki kekuatan terbatas dalam mengurangi opacity pendapatan di perusahaan keluarga. 
Kata Kunci: Transparansi informasi keuangan, opacity pendapatan, kepemilikan keluarga, independensi dewan, auditor eksternal

\section{Introduction}

The Corruption Perception Index report from 2012 to 2014 shows that $95 \%$ of Asian countries tend to have low levels of information transparency. Companies with concentrated ownership, particularly in the hand of families, are often linked with lower transparency of financial information (Anderson et al., 2009). Firms with a higher proportion of family ownership tend to have a lower level of earnings quality and a higher level of earnings management (Fung et al., 2013; Jaggi et al., 2009), which seems to potentially encourage family firms to limit the information presented to shareholders and the public. These conditions resulted in the poor transparency of corporate information, particularly in countries with relatively weak minority investor protection (Lang et al., 2012). The opposite view is shown by Nordin \& Hussin (2009) who find that family firms in Malaysia tend to disclose more transparent information to the public. Wang (2006) also find that family firms tend to provide a better quality of earnings. The different findings could be explained by the different view of transparency in family firms, due to entrenchment and alignment effects (Nordin \& Hussin, 2009; Srinidhi et al., 2014; Wang, 2006). The entrenchment effect explains how family firms are driven to improve financial statement information by taking opportunistic measures, such as management profit (Wang, 2006). Whereas, the effect of alignment shows how family firms deliver better information quality to protect the company's reputation and future performance.

Family firms may suffer from a conflict of interest, particularly through conflicts between majority and minority shareholders (i.e., agency conflicts type II) (Ali et al., 2007; Atmaja et al., 2011; Srinidhi et al., 2014). One way to mitigate this type II agency conflict is through the role of independent oversight both within and outside the company (Leung et al., 2014), which involves independent directors and external auditors (Fan \& Wong, 2005; Ianniello, 2013; Leung et al., 2014). Both roles are believed to be able to mitigate the type II agency conflicts (Fan \& Wong, 2005; 
Atmaja et al., 2011; Srinidhi et al., 2014). The independent oversight is not impartial to the management, and this could provide better protection to the minority shareholders (Fan \& Wong, 2005; Atmaja et al., 2011; Srinidhi et al., 2014).

However, the results of previous studies on the link between independent oversight and financial transparency in family firms are not always consistent. Independent directors can improve the performance of family enterprises by providing effective oversight, unbiased advice, and directing management. Moreover, the high proportion of independent directors of commissioners proved effective in reducing opportunistic measures (Atmaja et al., 2011; Leung et al., 2014). In contrast, other research finds that the role and proportion of independent directors are less effective in improving the transparency and quality of earnings of family firms (Jaggi et al., 2009; Nordin \& Hussin, 2009). Family firms view independent directors as a disruption that can hamper the decision-making process and potentially threaten the powers of founding family members (Leung et al., 2014).

Further, external auditors also serve an important role as the external oversight function of the company. External auditor with higher reputation tends to decrease the entrenchment effect and increase information transparency of family enterprise (Fan \& Wong, 2005; Lang et al., 2012). Srinidhi et al. (2014) show that the selection of qualified auditors by family firms is positively associated with higher transparency of financial reporting, higher quality of earnings information and lower audit risk. The findings are in contrast to the results of Zuhrohtun \& Baridwan's (2015) study which found that qualified auditors are not able to detect fraud by majority owners, thus unable to improve information transparency.

Based on the above discussion, within the context of firms in Asia, this study investigates the following research questions: (1) what is the relationship between family ownership and financial information transparency? (2) Is independent oversight moderates the relationship between family ownership and financial information transparency? This study complements previous research on the transparency of financial information on different types of ownership. We measure financial information transparency by using earnings opacity (Bhattacharya et al., 2003). 
This study provides some findings. First, we find a positive association between family ownership and financial information transparency. Second, firms with a higher proportion of independent directors tend to have a lower level of financial information transparency. Third, the type of external auditors (i.e., Big 4 auditors) in family firms are associated with lower level of financial information transparency.

\section{Theoretical Framework and Hypothesis Development}

\subsection{Agency Theory and Stewardship Theory}

Jensen \& Meckling (1976) defines agency relations as a contract between principal and agent to fulfill principal interests. In such relationship, conflict of interest arises when one of them pursue self-interest. The conflict between the principal and the agent is known as the Type I agency conflict (Srinidhi et al., 2014). Meanwhile, conflicts of interest in family firms occur mostly between majority and minority shareholders, which is known as the Type II agency conflict (Leung et al., 2014; Srinidhi et al., 2014).

Stewardship theory, on the other hand, explains how a manager is not merely motivated to achieve an individual goal, but rather to maintain (steward) his motivational alignment with the goals of the company owner (Davis et al., 1997). At the family enterprise, owners and managers tend to have an aligned interest (Chu, 2011) and tend to have lower self-interest/opportunism. As a consequence, family firms tend to have a better quality of financial information resulting in more transparent information (Ali et al., 2007; Nordin \& Hussin, 2009; Wang, 2006).

\subsection{Family Ownership and Transparency of Financial Information}

Transparency in a company is defined as the availability of company-specific information presented publicly (Bushman et al., 2004). Further, financial transparency is interpreted as more specific information to show the intensity and timeliness of financial disclosure by companies, interpretation of financial information by analysts and the dissemination of financial information by electronic media. As family firms tend to have better alignment of interests, firms tend to provide financial information 
that will be more transparent to the public, have lower levels of earnings management, higher earnings quality and greater disclosure (Ali et al., 2007; Atmaja et al. , 2011; Nordin \& Hussin, 2009; Wang, 2006). Wang's (2006) study proves that family ownership is positively related to the quality of financial information. In line with the argument, Srinidhi et al. (2014) find that family firms tend to have a higher quality of financial information. Anderson et al. (2009) also prove that ownership by founders and descendants of the founders become effective organizational structures in the corporate environment when the law governing investor protection is strong enough, and the information flaw in the company tends to be low.

Family firms in the United States signal that family control is used to limit corporate information disclosure to the public (Anderson \& Reeb, 2003; Srinidhi et al., 2014; Wang, 2006). However, unlike Asian countries where family ownership is a dominant form of organization and does not necessarily signify that family members have control over the company (Leung et al., 2012). Family firms can present more transparent information, high transparency in financial reporting by family firms or high investor demand for personal information will be useful and beneficial to the company itself (Nordin \& Hussin, 2009; Nguyen, 2011). Family firms with a high proportion of family ownership tend to choose efficient earnings management that is like increasing informed earnings in order to communicate personal information to the public (Siregar \& Utama, 2008). The results of the study in Asia illustrates that the high level of transparency by family firms because family companies still need capital support from external investors. Family firms that require capital from external parties should present more specific corporate information to investors. Also, family ownership is an effective form of ownership in Asia capable of presenting relatively transparent financial information and lowering opportunistic measures.

H1: Family firms will have a higher level of financial information transparency.

2.3 Family Ownership, Independent Director, and Financial Information Transparency

This study defines independent directors as independent management who provide checks and balances; they are expected to supervise and control the self- 
serving actions of non-independent directors over the interests of external shareholders (Nordin \& Hussin, 2009). The governance mechanisms supported by the strong function of independent directors tend to decrease agency conflict type II in family firms (Anderson \& Reeb, 2004; Atmaja et al., 2011; Srinidhi et al., 2014). The results of Anderson \& Reeb's (2004) study indicate that independent directors have a potential role as moderators between the relationship of family members in the company and the decrease of conflict between groups of shareholders. According to Leung et al. (2014), independent directors provide fairly strict supervision of managerial behavior, therefore the higher the proportion of independent directors, the higher the quality of financial information of the company. Atmaja et al. (2011) find that a high proportion of independent directors in family firms effectively reduces opportunistic actions through enhanced oversight mechanisms over company operations and can weaken family ownership and earnings management relationships. The ability of board independence in reducing agency conflict type II and decreasing opportunistic actions in family firms suggests the effectiveness of his role in overseeing all kinds of deviant actions and supporting the creation of transparency in the company.

H2: Board independence moderates the relationship between family ownership and financial information transparency.

\subsection{Family Ownership, External Auditor, and Transparency of Financial Information}

External auditors, as independent oversight to the firm, also plays a vital role as part of governance mechanisms. Thus they are expected to improve the quality of corporate reporting (Ianniello, 2013). According to Davidson \& Neu (1993), a quality audit is demonstrated by the auditor's ability to detect and eliminate errors and manipulations in reporting net income. Fan \& Wong (2005) proves that qualified external auditors can improve corporate governance mechanisms and reduce agency conflicts in firms with concentrated ownership.

Furthermore, Ianniello (2013) points out that qualified auditors can also enhance the protection of outside investors' equity and provide better protection to 
shareholders, particularly minority shareholders. Lang et al. (2012) find that firms which are audited by external auditors with a higher reputation tend to have more transparent financial information. Srinidhi et al. (2014) reinforce previous research evidence indicating that family ownership relations and financial information quality are stronger when firms choose qualified auditors. Accordingly, the following research question is proposed:

H3: The type of external auditors moderates the relationship between family ownership and financial information transparency.

\section{Research Methods}

\subsection{Data}

Data on information transparency, board independence, external auditors and family ownership are obtained from financial reports downloaded from the OSIRIS database. This study uses data from four countries in Asia with the selected research year is 2012 to 2014. Four Asian countries are selected to represent countries with a higher level of transparency (i.e., Japan and Singapore) and lower level of transparency (i.e., Indonesia and the Philippines). Based on non-financial companies which have a financial year ending on December 31, 217 family firms meet sampling criteria, resulting in a total of 651 firm-years during 2012-2014.

\subsection{Measurement of Research Variables}

\section{Financial Information Transparency}

Financial information transparency is measured using earnings' opacity. Transparency of financial information according to Qian et al. (2014) is the opposite of earnings' opacity. The degree of earnings' opacity in a country represents a failure of the state in distributing corporate earnings' reporting and the truth over the distribution of information, but can not be observed in a firm's economic profit in a country (Bhattacharya et al., 2003). There are three dimensions of profit opacity measurement, namely profit aggressiveness, loss avoidance, and income smoothing. The first dimension, i.e., profit aggressiveness is measured using accrual (earnings 
aggressiveness). There is a possibility that managers are compelled to report more favorable profits than under-serving. So the aggressive profit is a blurry profit because the accounting report is more likely to reflect biased and optimistic reporting from the management side, also add to the error in the reported earnings, therefore, can increase the opacity of profit. Here is the accrual calculation formula used by Bhattacharya et al. (2003):

\section{$A C C R U A L=(\triangle C A-\triangle C L-\triangle C A S H+\Delta S T D-D E P+\Delta T P) /$ $\operatorname{lag}(\mathrm{TA}) \ldots \ldots . . . .(\mathrm{EQ1})$}

With:

$\Delta \mathrm{CA}=$ Changes in the current asset, i.e., the total current asset of year $\mathrm{t}$ minus total current assets of year $\mathrm{t}-1$.

$\triangle \mathrm{CL}=$ Changes in current liabilities, i.e., total CL of year $\mathrm{t}$ minus total CL of year $\mathrm{t}-1$.

$\Delta \mathrm{CASH}=$ Changes in cash, i.e., cash in year $\mathrm{t}$ minus cash in year $\mathrm{t}-1$.

$\triangle \mathrm{STD} \quad=$ Change in short-term debt, i.e., the portion of long-term debt maturing in year $\mathrm{t}$ minus year $\mathrm{t}-1$.

DEP $=$ Depreciation and amortization expense in year $\mathrm{t}$.

$\Delta \mathrm{TP}=$ Changes of tax payable, i.e., tax payable in year $\mathrm{t}$ minus tax payable in year $\mathrm{t}-1$.

Lag $(\mathrm{TA}) \quad=$ Total assets of year $\mathrm{t}-1$

The second dimension of opacity is loss avoidance. Bhattacharya et al. (2003) define firms that have a small positive profit (small negative earnings) is a company with net income divided by total assets t- 1 is valued between 0 to 1 percent ( 0 to -1 percent). The ratio of the number of firms with small positive profits minus the number of companies with a small profit negatively divided by the total company for each year. The higher the ratio value in a country in year $t$ shows the higher the avoidance loss.

The third dimension, i.e., income smoothing, is measured using the correlation between accrual change divided by total assets t-1 and changes in cash flows divided by total assets of t-1antar companies in year t (Bhattacharya et al., 2003; Leuzet al, 2003; Qian et al., 2014). An increasingly negative correlation indicates a greater 
likelihood of income smoothing in a country that covers the variability in economic performance and is greater for profitability.

The value of opacity of earnings is derived from the average of three dimensions for each country in year t. In this study, it was not done by rating 1 to 10 as in Bhattacharya et al. (2003); Qian et al. (2014); Zuhrohtun \& Baridwan (2015). This is because the researchers did not test the effect of each dimension on family ownership as well as the distance of the study year is very short. Ranking primarily for the dimension of loss avoidance and income smoothing is not varied and inefficient, due to the presence of the same final value for each firm per year per country. Moreover, because profit opacity is the opposite of financial information transparency, the value of profit blurriness will be multiplied -1 to obtain the value of transparency of financial information.

\section{Family Ownership}

The family company category refers to Anderson \& Reeb (2003) and Wang (2006) explaining that a company is categorized as a family company if the founder or founding family owns the stock in the company and founding family members becomes part of the board of commissioners or top management. Second, family ownership is measured by the percentage of common stock ownership by founding family members, with the largest percentage showing the high level of family interest in the enterprise.

\section{Board Independence and External Auditor}

Board independence is measured by the ratio of independent directors by the total number of board members per company (Atmaja et al., 2011; Marraet al., 2011). The external auditor is measured using dummy variables, with " 1 " for companies audited by Big4 auditor and "0" otherwise. The control variables used in this research are SIZE, LEVERAGE, MBV (market to book value ratio), ADJROA, IP (investor protection), AS (accounting standard), and dummy years (i.e., 2013 and 2014). 


\section{Research Model}

The first hypothesis deals with the relationship of family ownership with the transparency of financial information. Here is a research model for hypothesis 1 .

$$
\begin{aligned}
\text {TIF }_{i t}= & \beta_{0}+\beta_{1} \text { Fam }_{i t}+\beta_{2} \text { SIZE }_{i t}+\beta_{3} L E V_{i t}+\beta_{4} M B V_{i t}+\beta_{5} A D J R O A_{i t}+\beta_{6} I P_{i t}+ \\
& \beta_{7} A S_{i t}+\beta_{8} D 2012_{i t}+\beta_{9} D 2013_{i t}+\varepsilon \ldots \ldots \ldots \ldots \ldots \ldots \ldots . \ldots(\mathrm{EQ2})
\end{aligned}
$$

The second and third hypothesis examines the moderating effect of independent control of the company. Therefore the equation 3 and 4 below are estimated to test $\mathrm{H} 2$ and $\mathrm{H} 3$, respectively:

$$
\begin{aligned}
& T I F_{i t}=\beta_{0}+\beta_{1} \text { Fam }_{i t}+\beta_{2} I B_{i t}+\beta_{3} F_{a m} * I B_{i t}+\beta_{4} S I Z E_{i t}+\beta_{5} L E V_{i t}+\beta_{6} M B V_{i t}+ \\
& \beta_{7} A D J R O A_{i t}+\beta_{8} I P_{i t}+\beta_{9} A S_{i t}+\beta_{10} D 2012_{i t}+\beta_{11} D_{2013}+\varepsilon \\
& \text { (EQ3) } \\
& \text { TIF }_{i t}=\beta_{0}+\beta_{1} \text { Fam }_{i t}+\beta_{2} \text { EA }_{i t}+\beta_{3} \text { Fam }_{i t} * E_{i t}+\beta_{4} \text {SIZE }_{i t}+\beta_{5} \text { LEV }_{i t}+ \\
& \beta_{6} M B V_{i t}+\beta_{7} A D J R O A_{i t}+\beta_{8} I P_{i t}+\beta_{9} A S_{i t}+\beta_{10} D 2012_{i t}+\beta_{11} D_{2013}
\end{aligned}
$$

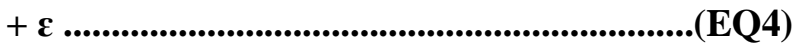

With:

$\mathrm{TIF}_{\text {it }}=$ Transparency of financial information, which is measured using earnings opacity, for firm i in year $\mathrm{t}$.

Fam $_{\text {it }} \quad=$ Family ownership, which is the percentage of ownership of common stock by the founding family member for company $\mathrm{i}$ in year $\mathrm{t}$.

$\mathrm{IB}_{\mathrm{it}}=$ Board independence, which is the ratio of independent directors to the total member of the board of commissioner for company $\mathrm{i}$ in year $\mathrm{t}$.

EA $_{\text {it }} \quad=$ External auditors is measured using a dummy variable, "1" for the company audited by auditor Big4 and "0" otherwise.

$\mathrm{SIZE}_{\mathrm{it}} \quad=$ Company size, which is measured using the natural logarithm of total assets of firm $\mathrm{i}$ in year $\mathrm{t}$. 
$\mathrm{LEV}_{\mathrm{it}} \quad=$ Leverage, which is measured using the ratio of total debt divided by total assets of firm $\mathrm{i}$ in year $\mathrm{t}$.

$\mathrm{MBV}_{\text {it }} \quad=$ Market to Book Value is measured using the ratio of equity market value divided by book value of equity of firm $i$ in year $t$.

$\mathrm{ADJROA}_{i t}=$ Adjusted ROA which is ROA adjusted and measured using net income divided by total assets minus median ROA of the industry of firm I in year t.

$I P_{i t} \quad=$ Investor Protection, which is a dummy variable "1" if the country has high investor protection, "0" if the country has low investor protection for firm $i$ in year t. (Houqe et al., 2012)

$A S_{i t} \quad=$ The accounting standard (Accounting Standard) is measured using the dummy variable "1" if the country has full IFRS, "0" otherwise.

D2012 ${ }_{i t}=$ "1" for 2012, "0" otherwise.

D2013 2 it $=$ "1" for 2013, "0" otherwise.

$\varepsilon \quad=$ error

\section{4. $\quad$ Result}

\subsection{Descriptive Statistics}

Table 1 presents the descriptive statistics of the sample data of this study. The dependent variable is the transparency of financial information (TIF) contained in panel A shows the average value of -0.097 . The independent variable in this study of family election (Fam) indicates that the average ownership of common stock by founding family members in the four countries amounts to 0.317 or $31.7 \%$. Moderating variables (i.e., board independence (IB) indicates that the average family company has $36 \%$ of independent directors. The second moderating variable, i.e., external auditors (Panel B) shows that as many as $63.1 \%$ of family companies choose Big 4 Auditors. 
Table 1

Descriptive Statistics $(\mathbf{n}=651)$

\begin{tabular}{|c|c|c|c|c|c|}
\hline Variable & Mean & Median & $\operatorname{Max}$ & Min & Std. Dev. \\
\hline \multicolumn{6}{|c|}{ Panel A (Continuous Variable) } \\
\hline TIF & $-0,097$ & $-0,054$ & 6,807 & $-0,551$ & 0,312 \\
\hline Fam & 0,317 & 0,263 & 0,972 & 0,000 & 0,259 \\
\hline$I B$ & 0,360 & 0,333 & 1,000 & 0,000 & 0,316 \\
\hline SIZE & 15,214 & 15,006 & 20,014 & 11,710 & 1,647 \\
\hline Total Assets & 18.032 & 3.287 & 4.920 .000 & 121 & 51.935 \\
\hline$L E V$ & 0,257 & 0,241 & 2,530 & 0,000 & 0,219 \\
\hline$A D J R O A$ & 0,054 & $-0,060$ & 76,550 & $-52,475$ & 8,680 \\
\hline$M B V$ & 1,283 & 1,015 & 41,932 & $-188,357$ & 7,817 \\
\hline \multicolumn{6}{|c|}{ Panel B (Dummy Variable) } \\
\hline & \multicolumn{2}{|c|}{ Dummy 0} & \multicolumn{2}{|c|}{ Dummy 1} & \\
\hline & $\mathbf{N}$ & $\%$ & n & $\%$ & \\
\hline$E A$ & 240 & 36,866 & 411 & 63,134 & \\
\hline$I P$ & 267 & 41,014 & 384 & 58,986 & \\
\hline$A S$ & 378 & 58,064 & 273 & 41,936 & \\
\hline
\end{tabular}

$\mathrm{TIF}=$ transparency of financial information is projected using profit blur that has three dimensions of profit aggressiveness, loss avoidance, and income smoothing. The value of profit opacity multiplied -1 to obtain the final value of TIF. The higher the TIF value indicates the information presented is more transparent and vice versa. Fam $=$ percentage of common stock held by family). IB = percentage of independent directors. EA = external auditor is an external auditor who is the auditor Big 4. SIZE = company size, the total natural logarithm of assets. Total Assets in the table are presented in billions. LEV = leverage (debt ratio) .ADJROA = ROA adjustment for industry level (adjusted ROA). $\mathrm{MBV}=$ equity book value ratio divided by the market to book value. IP = investor protection level at country level (Investor Protection) refers to Houqe et al. (2012).AS = adoption status of IFRS (Accounting Standard). D $2012=$ dummy year $(1=2012,0=$ otherwise), D $2013=$ dummy year $(1=2013,0=$ otherwise $)$.

\subsection{Results of Hypotheses Testing}

The first hypothesis states that family ownership has a positive influence on the transparency of financial information. Hypothesis testing uses panel pooled model data regression. Table 2 (Model 1) shows that family ownership variables are 
significant at alpha $1 \%$ with positive coefficients. Based on these findings the first hypothesis in this study is supported. This finding proves that the higher the percentage of shares owned by family members the more transparent the financial information presented, consistent with the results of Nordin \& Hussin's (2009) study. The results of this study also indicate that in family firms in Asia, the conflict of interest between owner and management (Type I) is relatively low. In line with the results of Atmaja et al. (2011) and Wang (2006) research, family members actively involved in corporate management will reduce their opportunistic behavior especially in limiting financial information to maintain corporate reputation.

The second hypothesis predicts that the presence of independent directors moderates the positive relationship between family ownership and financial information transparencydirectors. The result of interaction test of Model 2B in Table 2 shows that the interaction of family ownership and independent directors (Fam * IB) has a positive and insignificant effect. Thus, the second hypothesis is not supported. These results indicate that the proportion of independent directors in family firms is relatively low in encouraging corporate transparency. These findings are in line with those of Nordin \& Hussin (2009) and Jaggi et al. (2009) who find that the proportion of high independent directors does not play an important role in improving the company's performance as well as the transparency of financial information in family firms. These findings indicate that in family firms, independent board' role as monitoring mechanisms to reduce agency conflict between majority and minority shareholders are ineffective, which could be due to stronger family interventions in such firms. In family firms, family members tend to control the reappointment of independent directors. Therefore they tend to be less independent, take side with family decisions, and less critical to opportunistic action by management (Jaggi et al., 2009).

Further, the third hypothesis expects that the quality of the external auditor moderates the positive relationship between family ownership and financial information transparency. Model 3B (Table 2) shows that the coefficient on the interaction of family ownership and external auditor (Fam*AI) is significant in the 
negative. Thus the third hypothesis is not supported. The finding shows that qualified external auditors tend to weaken the have an effect on high corporate opacity and low transparency of financial information, highly qualified auditors cannot detect opportunistic actions by a family company. In line with the findings of Zuhrohtun \& Baridwan's research (2015) that qualified auditor differences are not able to reduce the level of earnings opacity or the auditor is unable to detect opportunistic management actions, i.e., blurring the earnings for personal gain. According to Bhattacharya et al. (2003), the earnings opacity by a company is difficult to observe in the firm's economic profit, making it clear that there is a qualified external auditor's inability to detect the opacity of profits by a family company. The existence of qualified external auditors in companies with a high percentage of family ownership cannot overcome the strength of family members' interventions in opportunistic decision making, resulting in increased profitability and low transparency of financial information.

\subsection{Additional Analysis}

Findings on the main model show that investor protection has a negative effect on information transparency, accordingly we the model by using different measurement for investor protection variable. Countries with strong investor protection are relatively low yielding transparency of information. Consistent with the results of Hansen et al. (2015), the level of transparency tends to increase significantly in countries with stronger investor protection compared to countries with weaker investor protection. However, Jeanjean (2012) argue that the size of investor protection used by Houqe et al. (2012) has some limitations.

Further, it is argued that the measurements developed by Djankov et al. (2008) provide an alternative measure of legal protection for minority shareholders against corporate expropriation and misuse of corporate assets for personal gain by directors. Accordingly, we use the investor protection index of the World Bank Doing Business 
Database as used by Haidar (2009) based on three dimensions of investor protection measures Djankov et al. (2008) ${ }^{1}$ in the additional analysis.

As shown in Table 3, in all models the finding shows that investor protection has a significant positive effect on the transparency of financial information on family firms in Asia. These results are consistent with Cahan et al. (2008) and Defond et al. (2007), which find that firms in a country with stronger investor protection tend to have higher information transparency, higher earnings quality, and lower opportunistic behaviors, compared to firms that reside in a country with weaker investor protection. Thus, the strength of investor protection in a country tend to encourage family firms to provide more transparent financial information.

The findings for Model 1 in Table 3 are still consistent with the previous testing, that family ownership affects the high transparency of financial information presented to the public as well as to stakeholders. Model 2A shows that board independence has a significant positive effect on the transparency of financial information at alpha $1 \%$. The findings are also consistent with earlier findings that the proportion of board independence is relatively improving the transparency of financial information of family firms. However, in contrast to the findings of Model 2B which shows that the interaction of the proportion of board independence and the percentage of ownership is significant at alpha $1 \%$ in a negative direction. The results explain that the interaction of the proportion of board independence and the percentage of family ownership tends to decrease the transparency of financial information.

This finding is also in line with the agency theory perspective explaining that the effect of family members' involvement is used to maximize personal gain and control resources and limit the functionality of board independence. According to Jaggi et al. (2009) that the increase in the proportion of board independence to strengthen

${ }^{1}$ The data can be accessed on www.doingbusiness.org. The value of the three dimensions of investor protection each year and each country is then averaged. Obtaining value above 5.0 is categorized as a country with high investor protection and vice versa under 5.0 countries with low investors. Based on these new measurements, three countries, namely Singapore, Indonesia, and Japan are categorized as countries with strong investor protection which subsequently enter the dummy criterion 1 , while the Philippines as a country with weak investor protection then goes to dummy criterion 0 . 
supervision tends to be less effective at companies under family control. According to him, board independence tends to be disturbed by the existence of family members' control either through domination of ownership or reappointment of the board who depend on the control of family members. Therefore, there is a tendency of board independence to side with family decisions that have an impact on decreasing independence, thus increasing the transparency of information is not achieved. Further test results for Model 3A and Model 3B are still consistent with previous findings that external auditors as moderators weaken family ownership relationships and transparency of financial information. Qualified external auditors have difficulty in detecting the opacity of profits by family firms when the percentage of family ownership is high.

\section{Conclusion, Implications, and Limitations}

\subsection{Conclusion}

This study aims to examine the relationship of family ownership and transparency of financial information to firms in Asia. The results show that the percentage of common stock ownership by founding family members can improve the transparency of financial information. Family firms in Asia also tend to avoid agency conflicts between principals and agents (Type I).

This research also adds the moderating effect of independent supervision, i.e., board independence and external auditors. The findings show that board independence has a vital role to play in the transparency of financial information in family enterprises. However, when the percentage of family ownership is higher, the oversight function of board independence declines. This could be due to the stronger control or intervention by family members, resulting in a decrease in financial information transparency. Further, the presence of independent directors in companies with a higher percentage of family ownership may be unable to reduce the conflict of interest between majority and minority shareholders (Type II agency conflict). 
Furthermore, our findings indicate that a more reputable external auditors are unable to reduce the earnings opacity in family firms.

\subsection{Implications}

This study provides some implications. First, the type of enterprise concentrated under family ownership in Asia tends to be effective in improving the transparency of financial information. Family firms can avoid Type I agency conflicts, but can not avoid agency conflict Type II. A higher percentage of family ownership tends to lead in the ineffective role of independent oversight of both internal and external companies. Companies with higher family ownership could be trapped in higher control/intervention by family members in making decisions, thus weaken independent supervision by independent directors and external auditors. The lack of independent oversight makes family firms give priority to family interests as majority parties rather than minorities. Further, a lower level of information transparency is mostly shown by family firms with small sizes. Lastly, strong investor protection in a country can encourage companies to increase the transparency of their financial information.

\subsection{Limitations and Suggestions for Future Studies}

This study has some limitations which provide avenues for future studies. First, this study only covers three years period. Future studies may extend the period to achieve a more comprehensive picture of earnings' opacity in a country. Second, this study measures financial information transparency by using earnings' oppression. Subsequent research may add variations in the proxy for financial information transparency, such as disclosure. Third, the measurement of family ownership in this study is based solely on the percentage of common stock ownership by founding family members. Subsequent research may create a percentage category of common stock ownership by family members, such as ownership categories above $20 \%$ or $50 \%$ which represent control over corporate decisions. Fourth, the quality of external 
auditors in this study is categorized based on Big4 and Non-Big4. Future research may include the size of external auditors, such as audit fees to demonstrate auditor risk.

\section{References}

Ali, A., Chen, T., \& Radhakrishnan, S. (2007). Corporate disclosures by family firms. Journal of Accounting and Economics, 44, 238-286.

Anderson, R. C., Duru, A., \& Reeb, D. M. (2009). Founders, heirs, and corporate opacity in the United States. Journal of Financial Economics, 92(2), 205-222.

Anderson, R. C., \& Reeb, D. M. (2003). American Finance Association Founding-Family Ownership and Firm Performance: Evidence from the S \& $\mathrm{P}$ 500. The Journal of Finance, 58(3), 1301-1328.

Anderson, R. C., \& Reeb, D. M. (2004). Board composition: balancing family influence in S\&P 500 firms. Administrative Science Quarterly, (49(2)), 209-237.

Atmaja, L. S., Haman, J., \& Tanewski, G. (2011). The role of board independence in mitigating agency problem II in Australian family firms. British Accounting Review, 43(3), 230-246.

Bhattacharya, U., Daouk, H., \& Welker, M. (2003). World Earnings Opacity. The Accounting Review, 78(3), 641-678.

Bushman, R. M., Piotroski, J. D., \& Smith, A. J. (2004). What determines corporate transparency? Journal of Accounting Research, 42(2), 207-252.

Cahan, S. F., Liu, G., \& Sun, J. (2008). Investor Protection, Income Smoothing, and Earnings Informativeness. Journal of International Accounting Research, 7(1), 1-24.

Chu, W. (2011). Family ownership and firm performance : Influence of family management, family control, and firm size. Asia Pacific Journal of Management, 28, 833-851.

Davidson, R. A., \& Neu, D. (1993). A Note on the Association between Audit Firm Size and Audit Quality. Contemporary Accounting Research, 9(2), 479-488.

Davis, J. H., Schoorman, D. F., \& Donaldson, L. (1997). Toward a Stewardship Theory of Management. The Academy of Management Review, 22(1), 20-47.

Defond, M., Hung, M., \& Trezevant, R. (2007). Investor protection and the information content of annual earnings announcements: International evidence. Journal of Accounting and Economics, 43, 37-67.

Djankov, S., La Porta, R., Lopez de Silanes, F., \& Shleifer, A. (2008). The law and economics of self-dealing. Journal of Financial Economics, 88, 430-465. 
Fan, J. P. H., \& Wong, T. J. (2005). Do external auditors perform a corporate governance role in emerging markets? Evidence from East Asia. Journal of Accounting Research, 43(1), $35-72$.

Fung, S. Y., Su, L. N., \& Gul, R. J. (2013). Investor legal protection and earnings management: A study of Chinese H-shares and Hong Kong shares. Journal of Accounting and Public Policy, 32(5), 392-409.

Haidar, J. I. (2009). Investor protections and economic growth. Economics Letters, 103(1), 14.

Hansen, B., Miletkov k., M., \& Wintoki, M. B. (2015). Investor Protection and the Role of Firm-Level Financial Transparency in Attracting Foreign Investment. The Financial Review, 50, 393-434.

Houqe, M. N., van Zijl, T., Dunstan, K., \& Karim, a. K. M. W. (2012). The Effect of IFRS Adoption and Investor Protection on Earnings Quality Around the World. International Journal of Accounting, 47(3), 333-355.

Ianniello, G. (2013). The effects of board and auditor independence on earnings quality: evidence from Italy. Journal of Management \& Governance, 19, 229-253.

Jaggi, B., Leung, S., \& Gul, F. (2009). Family control, board independence and earnings management: Evidence based on Hong Kong firms. Journal of Accounting and Public Policy, 28(4), 281-300.

Jeanjean, T. (2012). The Effect of IFRS Adoption, Investor Protection, and Earnings Quality: Some Reflections. International Journal of Accounting, 47(3), 356-362.

Jensen, M. C., \& Meckling, W. H. (1976). Theory of the firm: Managerial behavior, agency costs, and ownership structure. Journal of Financial Economics, 3(4), 305-360.

Lang, M., Lins, K. V., \& Maffett, M. (2012). Transparency, Liquidity, and Valuation: International Evidence on When Transparency Matters Most. Journal of Accounting Research, 50(3), 729-774.

Leung, S., Richardson, G., \& Jaggi, B. (2014). Corporate board and board committee independence, firm performance, and family ownership concentration: An analysis based on Hong Kong firms. Journal of Contemporary Accounting and Economics, 10(1), 16-31.

Leung, S., Srinidhi, B., \& Lobo, G. (2012). Family control and idiosyncratic volatility: Evidence from listed firms in Hong Kong. Journal of Contemporary Accounting and Economics, 8(1), 39-52.

Leuz, C., Nanda, D., \& Wysocki, P. D. (2003). Earnings management and investor protection: An international comparison. Journal of Financial Economics, 69(3), 505-527.

Marra, A., Mazzola, P., \& Prencipe, A. (2011). Board monitoring and earnings management pre- and post-IFRS. International Journal of Accounting, 46(2), 205-230. 
Nguyen, P. (2011). Corporate governance and risk-taking: Evidence from Japanese firms. Pacific-Basin Finance Journal, 19(3), 278-297.

Nordin, W., \& Hussin, W. (2009). The impact of family-firm structure and board composition on corporate transparency: Evidence-based on segment disclosures in Malaysia. International Journal of Accounting, 44(4), 313-333.

Picur, R. D. (2004). Quality of Accounting, Earnings Opacity, and Corruption. Review of Accounting \& Finance, 3(1), 103.

Qian, C., Gao, X., \& Tsang, A. (2014). Corporate Philanthropy, Ownership Type, and Financial Transparency. Journal of Business Ethics, 1-17.

Siregar, S. V., \& Utama, S. (2008). Type of earnings management and the effect of ownership structure, firm size, and corporate-governance practices: Evidence from Indonesia. International Journal of Accounting, 43(1), 1-27.

Srinidhi, B. N., He, S., \& Firth, M. (2014). The effect of governance on specialist auditor choice and audit fees in U.S. family firms. Accounting Review, 89(6), 2297-2329.

Wang, D. (2006). Founding family ownership and earnings quality. Journal of Accounting Research, 44(3), 619-656.

Zuhrohtun, \& Baridwan, Z. (2015). Determinants of Earnings Opacity: Indonesia Evidence. International Journal of Business and Finance Research, 9(3), 95-104. 
Table 2 Regression Result - TIF and Family Ownership

\begin{tabular}{|c|c|c|c|c|c|c|c|c|c|c|}
\hline \multirow{3}{*}{$\begin{array}{c}\text { Variable } \\
N=651\end{array}$} & \multirow{2}{*}{\multicolumn{2}{|c|}{$\begin{array}{c}\text { Without Moderation } \\
\text { Model 1 } \\
\end{array}$}} & \multicolumn{4}{|c|}{ Moderator: Board Independence } & \multicolumn{4}{|c|}{ Moderator: External Auditor } \\
\hline & & & \multicolumn{2}{|c|}{ Model 2A } & \multicolumn{2}{|c|}{ Model 2B } & \multicolumn{2}{|c|}{ Model 3A } & \multicolumn{2}{|c|}{ Model 3B } \\
\hline & Coef. & t-stat & Coef. & $t$-stat & Coef. & $t$-stat & Coef. & $t$-stat & Coef. & $t$-stat \\
\hline Intercept & 0,060 & $3,834 * * *$ & 0,041 & $2,490 * *$ & 0,045 & $2,483 * *$ & 0,027 & 1,549 & 0,012 & 0,744 \\
\hline Fam & 0,021 & $3,505 * * *$ & 0,031 & $4,608 * * *$ & 0,017 & 1,143 & 0,021 & $2,752 * * *$ & 0,046 & $3,346 * * *$ \\
\hline$I B$ & & & 0,084 & $9,733 * * *$ & 0,078 & $7,501 * * *$ & & & & \\
\hline$E . A$ & & & & & & & $-0,012$ & $-3,089 * * *$ & 0,001 & 0,118 \\
\hline $\operatorname{Fam}^{*} I B$ & & & & & 0,023 & 1,090 & & & & \\
\hline Fam*EAA & & & & & & & & & $-0,049$ & $-2,731 * * *$ \\
\hline$S I Z E$ & $-0,007$ & $-5,652 * * *$ & $-0,007$ & $-6,472 * * *$ & $-0,007$ & $-6,310 * * *$ & $-0,004$ & $-3,396 * * *$ & $-0,003$ & $-3,057 * * *$ \\
\hline$L E V$ & 0,034 & $3,195 * * *$ & 0,020 & $2,148 * *$ & 0,021 & $2,215 * *$ & 0,043 & $3,773 * * *$ & 0,037 & $2,889 * * *$ \\
\hline$A D J R O A$ & 0,000 & 0,489 & 0,000 & 1,575 & 0,000 & $1,669^{*}$ & $-0,000$ & $-0,417$ & $-0,000$ & $-0,079$ \\
\hline$M B V$ & 0,001 & $4,970 * * *$ & 0,001 & $4,947 * * *$ & 0,001 & $4,989 * * *$ & 0,001 & $4,793 * * *$ & 0,002 & $6.197 * * *$ \\
\hline$I P$ & $-0,243$ & $-35,889 * * *$ & $-0,230$ & $-34,835 * * *$ & $-0,233$ & $-34,033^{* * *}$ & $-0,241$ & $-35,043 * * *$ & $-0,241$ & $-36,219 * * *$ \\
\hline$A S$ & 0,184 & $28,064 * * *$ & 0,149 & $19,407^{* * *}$ & 0,152 & $19,522 * * *$ & 0,191 & $30,038 * * *$ & 0,196 & $30,909 * * *$ \\
\hline D2012 & 0,040 & $12,675^{* * *}$ & 0,038 & $12,584^{* * * *}$ & 0,039 & $12,307^{* * *}$ & 0,038 & $9,890 * * *$ & 0,032 & $7,844 * * *$ \\
\hline D2013 & 0,007 & $2,065 * * *$ & 0,008 & $2,524 * *$ & 0,008 & $2,421 * *$ & 0,005 & 1,278 & 0,005 & 1,368 \\
\hline Highest VIF & \multicolumn{2}{|r|}{1,472} & \multirow{2}{*}{\multicolumn{2}{|c|}{$\begin{array}{l}1,498 \\
0,902\end{array}$}} & \multicolumn{2}{|c|}{3,773} & \multicolumn{2}{|r|}{1,481} & \multicolumn{2}{|c|}{3,855} \\
\hline R-squared & \multirow{2}{*}{\multicolumn{2}{|c|}{$\begin{array}{l}0,875 \\
0,873\end{array}$}} & & & \multirow{2}{*}{\multicolumn{2}{|c|}{$\begin{array}{l}0,902 \\
0,901\end{array}$}} & \multirow{2}{*}{\multicolumn{2}{|c|}{$\begin{array}{l}0,882 \\
0,879\end{array}$}} & \multicolumn{2}{|c|}{$\begin{array}{l}0,889 \\
0,888\end{array}$} \\
\hline Adj. R-squared & & & \multicolumn{2}{|c|}{$\begin{array}{l}0,902 \\
0,900\end{array}$} & & & & & \multirow{2}{*}{\multicolumn{2}{|c|}{$\begin{array}{c}0,888 \\
468,939\end{array}$}} \\
\hline F-stat & \multicolumn{2}{|r|}{$\begin{array}{c}0,873 \\
468.9395\end{array}$} & \multicolumn{2}{|c|}{534,527} & \multicolumn{2}{|c|}{592,378} & & & \\
\hline Prob & \multicolumn{2}{|r|}{$p<0,001$} & \multicolumn{2}{|c|}{$\mathrm{p}<0,001$} & \multicolumn{2}{|c|}{$p<0,001$} & \multicolumn{2}{|c|}{$\begin{array}{c}477,664 \\
p<0,001\end{array}$} & \multicolumn{2}{|c|}{$\mathrm{p}<0,001$} \\
\hline
\end{tabular}

The average financial information transparency (TIF) of the three dimensions of profit opacity (eamings aggressiveness, loss avoidance, and income smoothing) multiplied (-1). Family ownership (Fam) is the percentage of ownership of common stock of founding family members. Board Independence (IB) is the percentage of independent directors. The extemal auditor (EA) is measured using dummy variables ( 1 for auditors Big 4,0 otherwise). SIZE is the total natural logarithm of the asset. Leverage (LEV) is the debt ratio. Adjusted ROA (ADJROA) is a ROA adjustment for industry level. Market to book value (MBV) is the ratio of book value of equity divided by the market value of equity. Investor Protection (IP) refers to Houqe et al. (2012). Accounting Standard (AS) is measured using dummy variables (1 for fully IFRS adopting countries, 0 for others). $\mathrm{D} 2012=$ dummy year $(1=2012,0=$ other year), $\mathrm{D} 2013=$ dummy year $(1=2013$, $0=$ other year). $* * *, * *, *$ significance coefficients at $1 \%, 5 \%$ and $10 \%$ 
Table 3 Additional Tests - Alternative Measurement for Investor Protection

\begin{tabular}{|c|c|c|c|c|c|c|c|c|c|c|}
\hline \multirow{3}{*}{$N=651$} & \multirow{2}{*}{\multicolumn{2}{|c|}{$\begin{array}{c}\text { Without Moderation } \\
\text { Model } 1 \\
\end{array}$}} & \multicolumn{4}{|c|}{ Moderator: Board Independence } & \multicolumn{4}{|c|}{ Moderator: External Auditor } \\
\hline & & & \multicolumn{2}{|c|}{ Model 2A } & \multicolumn{2}{|c|}{ Model 2B } & \multicolumn{2}{|c|}{ Model 3A } & \multicolumn{2}{|c|}{ Model 3B } \\
\hline & Coef. & t-stat & Coef. & $t$-stat & Coef. & $t$-stat & Coef. & t-stat & Coef. & t-stat \\
\hline Intercept & $-0,336$ & $-8,635 * * *$ & $-0,340$ & $-9,053 * * *$ & $-0,397$ & $-10,488 * * *$ & $-0,353$ & $-9,573 * * *$ & $-0,339$ & $-8,723 * * *$ \\
\hline Fam & 0,188 & $16,821 * * *$ & 0,205 & $20,389 * * *$ & 0,280 & $15,283 * * *$ & 0,180 & $16,401 * * *$ & 0,245 & $12,316 * * *$ \\
\hline$I B$ & & & 0,085 & $12,429 * * *$ & 0,137 & $12,416 * * *$ & & & & \\
\hline$E A$ & & & & & & & $-0,021$ & $-3,865 * * *$ & 0,029 & $2,877 * * *$ \\
\hline$F a m * I B$ & & & & & -0.184 & $-5,817 * * *$ & & & & \\
\hline $\operatorname{Fam}^{*} E A$ & & & & & & & & & $-0,145$ & $-6,295 * * *$ \\
\hline$S I Z E$ & $-0,009$ & $-5,992 * * *$ & $-0,008$ & $-5,479 * * *$ & $-0,006$ & $-4,378 * * *$ & $-0,007$ & $-4,740 * * *$ & $-0,009$ & $-4,888 * * *$ \\
\hline$L E V$ & 0,235 & $16,505 * * *$ & 0,201 & $15,647 * * *$ & 0,202 & $15,010 * * *$ & 0,234 & $15,859 * * *$ & 0,216 & $13,316 * * *$ \\
\hline$A D J R O A$ & 0,000 & 0,946 & 0,000 & 1,042 & 0,000 & 1,176 & 0,000 & 0,249 & $-0,001$ & $-1,382$ \\
\hline$M B V$ & 0,002 & $6,178 * * *$ & 0,002 & $5,951 * * *$ & 0,002 & $5,415 * * *$ & 0,002 & $7,214 * * *$ & 0,002 & $7,207 * * *$ \\
\hline$I P \_2$ & 0,247 & $10,162 * * *$ & 0,204 & $8,342 * * *$ & 0,209 & $8,382 * * *$ & 0,242 & $10,077 * * *$ & 0,229 & $9,899 * * *$ \\
\hline$A S$ & 0,072 & $12,149 * * *$ & 0,052 & $8,984 * * *$ & 0,046 & $8,040 * * *$ & 0,079 & $12,475 * * *$ & 0,080 & $12,036 * * *$ \\
\hline D2012 & 0,035 & $6,508 * * *$ & 0,036 & $9,062 * * *$ & 0,039 & $8,562 * * *$ & 0,035 & $6,119 * * *$ & 0,023 & $3,954 * * *$ \\
\hline D2013 & 0,003 & 0,700 & 0,003 & 0,802 & 0,003 & 0,653 & 0,005 & 0,957 & $-0,006$ & $-0,971$ \\
\hline Highest VIF & \multicolumn{2}{|c|}{1,414} & \multicolumn{2}{|c|}{1,769} & \multicolumn{2}{|c|}{3,808} & \multicolumn{2}{|c|}{1,437} & \multicolumn{2}{|c|}{3,905} \\
\hline R-squared & \multicolumn{2}{|c|}{0,572} & \multicolumn{2}{|c|}{0,666} & \multicolumn{2}{|c|}{0.666} & \multicolumn{2}{|c|}{0,587} & \multicolumn{2}{|c|}{0,529} \\
\hline Adj. R-squared & \multicolumn{2}{|c|}{0,566} & \multicolumn{2}{|c|}{0,661} & \multicolumn{2}{|c|}{0,660} & \multicolumn{2}{|c|}{0,581} & \multicolumn{2}{|c|}{0,521} \\
\hline F-stat & \multicolumn{2}{|c|}{95,406} & \multicolumn{2}{|c|}{127,599} & \multicolumn{2}{|c|}{115,770} & \multicolumn{2}{|c|}{91,017} & \multicolumn{2}{|c|}{65,399} \\
\hline Prob & \multicolumn{2}{|c|}{$\mathrm{p}<0,000$} & \multicolumn{2}{|c|}{$\mathrm{p}<0,000$} & \multicolumn{2}{|c|}{$\mathrm{p}<0,000$} & \multicolumn{2}{|c|}{$\mathrm{p}<0,000$} & \multicolumn{2}{|c|}{$\mathrm{p}<0,000$} \\
\hline
\end{tabular}

The average financial information transparency (TIF) of the three dimensions of profit opacity (earnings aggressiveness, loss avoidance, and income smoothing) multiplied $(-1)$. Family ownership (Fam) is the percentage of ownership of common stock of founding family members. Board independence (IB) is the percentage of an independen board. The external auditor (EA) is measured using dummy variables ( 1 for auditors Big 4, 0 for others). SIZE is the total natural logarithm of the asset. Leverage (LEV) is the debt ratio. Adjusted ROA (ADJROA) is a ROA adjustment for industry level. Market to book value (MBV) is the ratio of book value of equity divided by the market value of equity. Investor Protection (IP) refers to Haidar (2009). Accounting Standard (AS) is measured using dummy variables (1 for fully IFRS adopting countries, 0 for others $)$. D $2012=$ dummy year $(1=2012,0=$ other year $), D 2013=$ dummy year $(1=2013,0=$ other year $) * * *, * * *$ significance coefficients at $1 \%, 5 \%$ and $10 \%$ 